\title{
Balkanologie
}

Balkanologie Revue d'études pluridisciplinaires

Vol. V, no 1-2 | 2001

Volume V Numéro 1-2

\section{Paradigm Lost :Yugoslav Self-Management and the Economics of Disaster}

\section{P. H. Liotta}

\section{(2) OpenEdition}

1 Journals

\section{Édition électronique}

URL : http://journals.openedition.org/balkanologie/681

DOI : 10.4000/balkanologie.681

ISSN : 1965-0582

Éditeur

Association française d'études sur les Balkans (Afebalk)

Édition imprimée

Date de publication : 31 décembre 2001

ISSN : 1279-7952

Référence électronique

P. H. Liotta, «Paradigm Lost :Yugoslav Self-Management and the Economics of Disaster », Balkanologie [En ligne], Vol. V, n 1-2 | 2001, mis en ligne le 31 mai 2008, consulté le 17 décembre 2020 URL : http://journals.openedition.org/balkanologie/681; DOI : https://doi.org/10.4000/balkanologie. 681

Ce document a été généré automatiquement le 17 décembre 2020.

(c) Tous droits réservés 


\title{
Paradigm Lost :Yugoslav Self- Management and the Economics of Disaster
}

\author{
P. H. Liotta
}

\begin{abstract}
Democracies create free markets that offer economic opportunity, make for more reliable trading partners and are less likely to wage war on one another. While democracy will not soon take hold everywhere, it is in our interest to do all that we can to enlarge the community of free and open societies, especially in areas of greatest strategic interest, as in Central and Eastern Europe. ${ }^{1}$

I believe it is easier to wage war than to organise [sic] the government and direct social development, because these are complicated matters. ${ }^{2}$
\end{abstract}

1 During much of the 1990's, American foreign policy consistently emphasized the promotion of democratic values and free market reforms as stabilizing influences and forces for increased state and regional prosperity ${ }^{3}$. The ideological bases for these policy influences, no matter how valid in principle, have failed to sufficiently appreciate that Yugoslav disintegration was itself reflective of a larger European transformation from socialist structures to market economies and democratic practices. Such transformation holds the potential for increased regional interdependence and prosperity as much as it provides the means for descent into economic disaster and societal collapse.

2 From an ecological perspective, the human and technological potentials that democratic practices and economic reforms provide can prove disastrous if specific aspects predominate (such as, for example, would happen with a sharply increased emphasis on laissez-faire private market incentives to the detriment of public, social guarantees). With regard to democracy, a number of policy scholars have already noted the rise of "illiberal democracy"4. A White House diplomatic envoy expressed the significance of this "illiberalism" on the eve of democratic elections in September 1996 in Bosnia-Herzegovina, when he pondered the real possibility that "free and fair" democratic elections might well lead to the publicly supported selection of "racists, fascists, [and] separatists who are publicly opposed to [peace and reintegration]" ${ }^{5}$. Such 
democratic practice, however, reflects the potential failure of constitutional liberalism (a process and a tradition that respects both individual liberty and the rule of law) to have taken deep root in the post-Cold War era in the "new" Europe, despite the promise and optimism both diplomats and policymakers saw in the Cold War's aftermath ${ }^{6}$.

Further, the promise that democratic institutionalization could eventually bring to evolving governments and social structures in Central and Eastern Europe, as well as in the nations of the former Soviet Union, can equally conflict with too rapidly enforced economic change. The economic reforms that foreign creditors and "Western" governments essentially demanded of Yugoslavia in its final days required an authoritarian regime to voluntarily reduce its own powers even as contrarian human and technological forces demanded that the Yugoslav government retain what little authority it still possessed in order to provide a stable civic order, sufficient legal enforcement, and a living standard that could meet the expectations of a socialist order 7 . In such a case, the intent of democratic practice and economic reform to bring about positive change in a society proved counter-productive, and determinedly disastrous, by the introduction of too rapid change.

The failure of the Yugoslav state to provide such necessary order during a time of variously attempted economic and democratic reforms was a factor that allowed ultra-"nationalist" forces to take hold, forces that opposed the continuation of a "Yugoslav" state. These opposing forces (Croatian President Franjo Tudjman, Serbian and later "Yugoslav" President Slobodan Milošević, and 1997 candidate for the Serbian presidency, Vojislav Šešelj) proved essential to the ending of Yugoslavia. The state's failure to provide social order and social guarantees in a time of social transformation virtually assured its inevitable decline.

5 Serbia, treated as the pariah Balkan state by the West ever since the last days of the Yugoslav state in 1991, failed to achieve either democracy or economic reform by the end of the decade. (In the fourth, failed run-off election of 21 December 1997, a Serbian voter bluntly pronounced the dilemma facing voters in his nation: "We have a communist and a fascist for the two presidential candidates. What kind of democratic choice is that ? $\|^{8}$.) By 1998 , Serbia had come to represent the conditions of social chaos that economic and foreign policy scholar Susan Woodward warned of in 1995 :

Economic reforms such as those demanded of Yugoslavia (...) ask for political suicide. (...) Without a stable civil and legal order, the social conditions that are created can be explosive: large-scale unemployment among young people and unskilled urban dwellers; demobilized soldiers and security police looking for private employment; thriving conditions for black market activities and crime; and flourishing local and global traffic in small arms and ammunition'.

6 Former Yugoslavia thus provides a pertinent example of how the pressures of societal expectations coupled with a mounting foreign debt crisis can erode social fabric and accelerate declining living standards; further, such decline in a condition of weak state authority and intrastate tensions can often lead to conflict. From a social and strategic management perspective, the lessons of post-Yugoslav Serbia as well as BosniaHerzegovina foretell a potentially bleak future for European stability.

7 Ironically, the innovation of Yugoslav "Self-Management", or "Self-Government"-a double meaning for the same word in Serb-Croatian, samoupravljanje-once considered a benchmark in creative economic reform within a socialist society, proved to be a major contributing factor in the death of Yugoslavia. An examination of both the 
promise and lost opportunities of self-management might provide an appropriate-and cautionary-paradigm for the integration of the ideologies of democracy and free market reforms within an evolving Europe in a new century.

\section{The Promise of Self-Management}

8 Despite the intentional claim by the post-World War II Yugoslav government to have found precedent for Yugoslav "Communism" in the writings of Karl Marx, the evolution of self-management rose directly from the experience of the war itself. As a nation, Yugoslavia had only existed in political union since 1918, a stepchild, as it was, of the Treaty of Versailles. During World War II, however, that "union" had shattered along ethnic lines and fierce fighting among indigenous "Yugoslav" forces (such as Ustaše, ^etnici, Bela Garda, Domobrani, and Partisans) in an area of complete Nazi occupation. At the same time, Yugoslav Partisan resistance to overwhelming Nazi power-in terms of forces-proved so effective that British Prime Minister Winston Churchill argued successfully to switch Allied allegiance from the Yugoslav Chetnik resistance fighters to the Partisans, led by a Croat-Slovene named Josip Broz-in later years, simply known as "Tito" 10 .

9 Tito's subsequent independence of thought and demands for sovereignty for his postWorld War II state led to an inevitable collision with Joseph Stalin, the nominal ideological world leader for the Communist movement. Stalin's furor over Tito's refusal to adhere to Marxist-Leninist doctrine above a national "South Slav" affiliation led to Yugoslavia's expulsion from the International Communist organization, the Cominform, in $1948^{11}$. This tension between the Soviet Union would last until 1955, culminating in the state visit of Nikita Kruschev to Belgrade ${ }^{12}$. (Yugoslavia's peaceful separation from the USSR also influenced the Hungarian uprising of 1956 and the Czechoslovak movement known as "Socialism with a human face" in the spring of 1968.) Yugoslavia, in the late 1940's, grew convinced of a Soviet invasion through the province of Vojvodina (which bordered Hungary) and both re-located industry from Serbia into Croatia and Slovenia and thought creatively about new, independent ways to strategically manage the social framework of a "new" Yugoslav state.

One of the unique aspects of such individual and creative strategic innovation was the creation of Yugoslav self-management. In theory, the pivot of Titoism maintained that socialism would dictate the "withering away of the state"-an idea in direct opposition to the Soviet strategic management of a bigger, increasingly stronger, increasingly centralized state ${ }^{13}$. Tito recognized the Soviet model of government ownership of the means of production as little more than a fiction. He thus pushed for sweeping decentralization and economic liberalization. Under Tito, then, the worker's selfmanagement system was meant, in its purest conception, to provide the opposite of a Soviet-type dominance over the worker ; the "new" Yugoslav worker, by contrast, was intended to have democratic control and a democratic voice in the daily activity of work. In retrospect, five decades later, this visionary social management seems extraordinary.

In a prescient image of management texts and innovative articles on new management thinking (found most often in the Harvard Business Review) at the millennium's end ${ }^{14}$, self-management sought innovation in a system that resembled an inverted pyramid in which workers from the lower echelons controlled and mandated the decisions made 
by higher management. Yugoslav self-management was, in theory at least, akin to democracy-tied to the tenet that basic decisions would be made by the workers who would have to carry out such decisions or be most affected by them ${ }^{15}$. Worker's councils, composed of as many as 50 individuals in large factories, represented the "will" of the worker. Further, since the state itself was intended to wither away, political leadership attempted to shift responsibilities to the worker's commune-or opština (općina) -which was meant, in turn, to raise its own funds, sets its own budgets, and provide workers with necessary social services ${ }^{16}$.

Thus, the factory was meant to be an autonomous and competitive organization. Selfmanagement represented « an indirectly controlled market economy, with elements of Keynesianism [that is, based on the economic theories of John Maynard Keynes] as well as Marxism $»^{17}$. The worker's council was the basic operations unit-deciding what and whom to pay, what wages to give, how best to reallocate profits after taxes and operating costs were made. Unlike a capitalist economy in which shareholders determine both the allocation of resources and decide on how best to use capital, selfmanagement provided a system whereby workers themselves were shareholders. The worker was not able to individually invest his or her earnings but would reap in the collective wealth of the organization. The worker's only task was to make a profit for the organization.

The National Assembly of Yugoslavia adopted the Worker's Self-Management Act on 26 June 1950 ; it was not until 1952, however, that relevant portions of the Act took hold in the economic transition that attempted to allow more independence for enterprises, broader worker rights, and to introduce elements of market practices ${ }^{18}$. Workers, in a legally mandated precedent, could-through elected worker's councils-approve enterprise plans and accounting, make management decisions, make initial regulations, dismiss management committees that proved unsatisfactory, and distribute profits after taxes ${ }^{19}$.

In accordance with Marxist theory, the core root of inequality between individuals and classes is the ownership of the means of production; thus, the search for new paradigms led to self-management socialism. Private ownership was thus allowed in the production of various crafts, agriculture, services, transport, catering and tourism, but the contribution of these "industries" to overall Gross Domestic Product was small ${ }^{20}$.

15 Self-management, by contrast, both in its conception and during its first decade of existence, seemed to hold the promise of individual "de-alienation, the liberation of work, and direct democracy" for large-scale industry. Indeed, self-management provided a model that a number of other countries sought to replicate in their own societies to improve both efficiency and worker contributions ${ }^{21}$.

There appears never to have been any official declaration on the aims of selfmanagement. As Harold Lydall notes ${ }^{22}$, however, it is reasonable to claim that the general aims of self-management were to create an "industrial democracy," one in which workers held the same right of control (and censure) over policy as citizens in a democracy nominally hold similar control over their own government. Thus, in its time, Yugoslavia proved itself a maverick state, one neither Western nor Sovietinspired ${ }^{23}$. attention, and this innovation, lay the system of Yugoslav self-management socialism, 
one in which workers participated in decision-making at the enterprise level. Since democracy remained a titular desirable aim of both Communist and socialist governments, self-management in itself would appear to be in concert with such aims. Further, while it might appear premature to argue that self-management from its inception in 1950 was an intentional move to decentralize control from Belgrade and move toward a loose federation of republics (that led to the disintegration of the Yugoslav state in 1991), the concept of "the withering away of the state" remained, in proclamation at least, a desired goal. In reality, various economic pressures in the 1960's helped bring about this potential while no sufficient alternative arose to replace the state that had withered away.

\section{The Failure of Self-Management}

18 From 1952 to 1965, Yugoslavia witnessed the golden age of its economy, rivaling Japan as the fastest growing worldwide economy ${ }^{24}$. Labor-managed firms seemed to allow freedom of choice and direction for workers; equally, self-management was an indicator both of a market economy taking root and the presence of economic democracy within Yugoslavia. From 1950-1985, only Taiwan (6,64 percent), Japan (6,26 percent) and China $(5,10)$ produced Gross National Product (GNP) rates that exceeded Yugoslavia's $(4,46)^{25}$.

In particular, the year 1960 saw Yugoslavia «riding a wave of unprecedented prosperity ${ }^{26}$. Agricultural yields, the rise in imports, demand in consumer goods along with extended lines of consumer credit were as high as ever. Yugoslavia, the "different" Communist state, attracted worldwide attention. By 1962, overextension of credit, a rapid decline-and eventual depletion-of personal savings, and a failure in industrial output to match the boom in demand brought serious consequences that the miracle of the 1950's could not sustain ${ }^{27}$.

The Communist Party of Yugoslavia (CPY) finance minister who most furthered early Yugoslav economic reform (beginning in May 1952) was a Macedonian named Kiro Gligorov (who became the first president of independent Macedonian in 1991). Gligorov attempted to bring wage goods back into line, devalued the Yugoslav dinar in order to stimulate export production, while simultaneously cutting public expenditures and loosening state control over financial accountability in order to release available resources for manufacturers. One consequence of his actions, nonetheless, was the rise in corrupt misuse of such loosened financial accountability and the subsequent abuse of funds as newly available "working capital" was released to various industries ${ }^{28}$.

There are a number of causes for the failure of self-management. Perhaps the simplest and most viable explanation is that of "the psychology of rising expectations ${ }^{29}$. As Lydall notes, the naïve belief that workers, given the right to elect councils and be consulted with referenda would equally act to safeguard the interest of "society" was an inherent flaw $^{30}$. Workers were excluded from significant decisions, a truth best indicated by the evidence that executive appointments of top-level "directors" rested firmly in the hands of Yugoslav politicians ${ }^{31}$. Indeed, the irrelevance of workers' councils, the one body over which all workers have the democratic right to control and censure enterprise, was demonstrated during the wave of strikes that began in 1987. Workers demanded an increase in income; their demands were passed directly to enterprise "directors", and bypassed workers' councils. 
22 A brief consideration of the rapid rise in "work stoppages"-an essential Yugoslav euphemism for "strike"-reveals a striking parallel with the general societal declines that led to the disintegration of the Yugoslav state. In 1987 there were 1262 work stoppages (involving 196000 workers), decidedly more than the 851 strikes for 88860 workers in $1986^{32}$; in 1988, the number of strikes rose to 1720 strikes involving 388000 workers $^{33}$. (Although strikes were commonplace for years, the right to strike was not constitutionally guaranteed until November 1988 ; in 1989, the law itself was under fierce debate in the federal assembly.) By 1990, the number of yearly strikes had risen to 1900 strikes, involving 470000 workers, and an inflation rate that soared to 2500 percent $^{34}$. By 1990, in the final months of the Yugoslav state, the national labor federation (CITUY) of Yugoslavia, had become an empty shell ; worker unions tended to align with nationalist allegiances within specific republics (or with dominant ethnic groups within republics) ${ }^{35}$.

The transformation of union leaders from government mouthpieces to "democratic" representatives for workers' rights also took root in the late 1980's. Leaders began to advocate workers' interests on matters such as the impact of inflation, standard of living, and wage policies. (Under self-management, union leaders, by contrast, had played a minor role in representing workers' interest in the management of enterprise, distribution of income, settlement of disputes, and conduct of strikes.) By 1988, there was a clear distinction between the official Council of Trade Unions of Yugoslavia, which supported official government policy, and local trade union trade union leadership, which increasingly represented worker rights in establishing unprecedented strike codes and arguing for wage policies to prevent income losses that amounted to a reduction in real wages earned of 21,5 percent in one year ${ }^{36}$.

As Lydall has noted, for any enterprise to work efficiently it must have an efficient enterprise structure, effective management, and incentives and discipline ${ }^{37}$; selfmanagement, in its actual form, possessed none of these features. Thus, the rising number of strikes against enterprise proved a significant event. In a purely competitive and "free" self-management system, workers would have no reason to strike against themselves. In practice, nonetheless, the high degree of government intervention in enterprise affairs provoked adverse reaction in workers. Workers were striking not against enterprise, but against government policy ${ }^{38}$.

Eventually, self-management's potential could not be sustained by the system that created it (particularly by those republics that never intended to remain in Yugoslavia). The 1974 amendment to the federal constitution of Yugoslavia essentially institutionalized the autonomy of the six Yugoslav republics, thus implicitly allowing the acceleration of national - economic- and ethno-centrisms.

26 Yugoslavia's unique brand of socialism and capitalism also thwarted private initiative, effectively renouncing individual aims as "selfish". Self-management, in practice, promoted «the formation of an economic system [that fostered] equality rather than differentiation according to unequal ability ${ }^{39}$. Non-profitable firms could not be sold ; thus, firms in a socialist economy could operate under a soft budget constraint ${ }^{40}$.

27 From 1979 to 1985, in a kind of mirror event of the larger decline in industry production, social product services fell significantly. Education, health, and housing services were unable to meet the demand of rising social needs. Productivity fell by 20 percent ; workers' incomes fell by 25 percent ; by 1987, inflation was at 150 percent per annum $^{41}$. By contrast, from 1952 to 1975, inflation had peaked only once-from 1965 to 
1966-rising to 30 percent $^{42}$. Further exacerbating the problem of disintegration was economic polarization: by the 1980's personal income in the southern Yugoslav Republic of Macedonia was less than half that of the northern Republic of Slovenia ; in the southern autonomous province of Kosovo, the increased number of so-called "peasant" households and larger family sizes equally accentuated economic difference ${ }^{43}$.

The ultimate failure of self-management thus lay perhaps in the failure of the "withering away of the state"-or the socialization of centralized government to lower levels of effective, instrumental, self-managed budgets ${ }^{44}$. Demographics illustrated that the Yugoslav work force, responding to state initiatives, had increasingly moved from private, subsistence agriculture into a public sector that could not grow at a pace sufficient to supply the jobs required by such displacement ${ }^{45}$. Eventually, and at its most basic and divisive level, self-management became a forum for struggles over wages within the workplace.

The supposed harmonizing influence of the Communist Party of Yugoslavia became one more element in the fracturing of economic division :

Conflicts over substantive policy were redefined as conflicts over the distribution of money-over budgetary revenues and tax policy, transfers and subsidies, and the

locus of control over monetary policy, foreign exchange allocation and banking ${ }^{46}$.

One perhaps minor but illustrative example of the federal government's inability to meet transformed social and societal expectations occurred in 1987, when a conference titled "Possibilities for Reform in Socialist States", sponsored by the Center for Philosophy and Social Theory, was canceled at the final moment, possibly out of concern for adverse reaction from Warsaw Pact states ${ }^{47}$.

31 A larger example of the state's inability to accept criticism was reflected in published law that forbade criticism of both former President Tito and Socialist selfmanagement ; dissident Jovan Opačić, for example, was jailed in 1989 after interrupting an official commemoration in Knin and being charged with « committing a criminal act against Social self-management (...) and against the reputation of Yugoslavia $»^{48}$.

By 1991, the self-management system was being phased out. Economic reforms begun in 1990, had attempted to reduce government regulation, reform the banking system, expand private competition and encourage foreign investment. Such reform attempts had collapsed by 1991 under the pressures of high inflation, decreased production rates, high unemployment, and increasing fracturing of the economy along republic and ethnic lines ${ }^{49}$.

\section{The « Ecological » Meaning of Failure}

Marshal Tito's 1974 constitutional reform appears now to have created two ironic contradictions. In political terms, Tito, it seems obvious, wanted to ensure no leader of his particular and central stature in the Yugoslav state could replace him as ikon; this explains the establishment of a federal presidency that was little more than a figurehead position ${ }^{50}$. In economic terms, Tito's decentralized system was meant to delegate power and authority to republics and local governments in order to preserve stability among various conflicting ethnic nationalities. 
The effects of decentralization may indeed have prolonged the eventual death of the Yugoslav state. At the same time, however, the removal of effective power from a central government contributed to the ineffectiveness of government reforms in the last days of the Yugoslav state. Self-management in its true sense, nevertheless, provided a number of advantages over a Marxist-Leninist-Stalinist type economy. Not only did the system allow for competition between similar enterprises, it allowed equally for worker and manager innovation and the practice of free market-type relations. Thus, in the 1950's and 1960's, Yugoslavia experienced rapid economic progress.

At the same time, inherent system weaknesses led to economic stagnation. These weaknesses include the truth that under a laissez-faire self-management system there still would not exist the competitive "spur" of private enterprise ; under socialist selfmanagement, such as in Yugoslavia-in which workers had no ownership rights-no potential existed to influence decisions on investment, technology, or management appointments ${ }^{51}$. With over 500 communes and power distributed to various republics and political elites, the Yugoslav federation had indeed created the "dictatorship of the Proletariat" ${ }^{2}$. Thus, although Yugoslav self-management differed significantly from the negative, Stalinist model in how it encouraged initiative both in economic and political life, it still contained essential flaws. In the truest sense, the Communist model of "Reward according to need" transformed, in Yugoslav ideology, to "Reward according to work" and finally to "Reward according to the results of work" 53 . The essential problem remained that rewards lagged increasingly behind any expectation of results during the 1970's and 1980's.

According to Mencinger, self-management passed through four distinct systemic phases during its existence: administrative socialism (1945-1952); administrative market socialism (1953-1962) ; market socialism (1963-1973) ; and contractual socialism (1974-1988), followed by collapse ${ }^{54}$. These phases, in the space of four decades, mark the shift from an agricultural, capitalist society into an industrial socialist society.

An alternate perspective shows the extraordinary determination of the Yugoslav people to transform themselves in the wake of World War II-a war which was both an internecine civil war (among various warring Serbian, Croatian, and Macedonian elements) and a war for national "liberation" from Nazi occupation under Marshall Tito. It was perhaps only through Tito's iron rule (in which he purged dissident elements and maintained an extraordinarily efficient secret police) that such transformation from a largely agricultural to industrial societal base could take place.

The unique aspect of the Yugoslav experience is that its Communist government in the early years, unlike other East European nations, enjoyed widespread popular support, largely because of its determined resistance to Nazi occupation ${ }^{55}$. Thus, although the Communist regime was able to withstand the pressures of decentralization (which began in 1974) far longer than other East European nations that fractured quickly in the last days of 1989 , the rise of fractious nationalist identities, along with the inherent truth that meeting the needs of workers without accompanying economic growth seemed increasingly difficult, proved to be disastrous "ecological" elements for the state $^{56}$.

In retrospect, those who still favor a self-management system that is in theory, correct, seem somehow unable to recognize the truth of one Yugoslav economist's comment that self-management was a system « for angels and not for men ${ }^{57}$. The façade of self- 
management, as Zagorka Golubović has rightly noted, lies in the inherent incompatibility between democratic practice and the control of a one-party Marxist state. Self-management was bound to fail because workers and enterprise itself had no real influence-despite the claims of the (one-party Marxist) state-on decision making, production process, or social policy ${ }^{58}$. The reasons for failure can be thus summarized, briefly, as :

1. Yugoslav society rested on a form of control from a single "all encompassing" ruling ideology. This reality excluded the basic principles of self-organization, selfdetermination, self-management, and self-government.

2. The real authority of the state allowed, at best, a "paternalistic selfmanagement." Self-management was an appendage to the state, rather than its alternative.

3. Self-management was developed by those who implemented Stalinist post-war development in Yugoslavia until 1948. Thus, self-management was neither a form of social innovation nor a theoretical reassessment of the Soviet model, but rather a form of appropriation in the hands of those who maintained real power ${ }^{59}$.

Further, according to Adamović and Pavlović, five significant factors impeded Yugoslavia's democratic transition, and by extension true market reform, in the late 1980's :

1. The pressures for change were not as radical in Yugoslavia as in other East European countries after the fall of the Berlin Wall.

2. Post-Cold War Yugoslavia failed to make radical democratic changes.

3. Yugoslavia had wedged itself, during the Cold War, between bipolar superpowers and was slow to appreciate the meaning of the changed international order.

4. The power of one-party and one-person (Marshall Tito) politics destroyed Yugoslavia's ability to create independent political identities;

5. Socialism itself retarded the development of civil society ${ }^{60}$.

Although the Law of Enterprise of January 1989 is generally considered the official "ending" of self-management, 18 actual laws passed in the period 1988 to 1989 marked the effective end of self-management ${ }^{61}$. Then Prime Minister Ante Marković's "shock therapy" stabilization program in the spring of 1990, coupled with liberalizing economic measures to include full foreign ownership, seemed to hold the potential for a Yugoslav recovery. Such recovery, if only an economic one, could not take place in isolation from other pressures. In December 1990, the Slovene electorate voted for full national independence by June 1991 and subsequent accompanying demands by both the Croatian and Slovenian governments to assume federal jurisdiction over legislation, laws, administration of justice, and police enforcement, which led not to further confederation and decentralization but to civil war.

From 1963 to 1973, the slowdown in economic progress coupled with rising unemployment and accompanying social pressures virtually assured the end of the Yugoslav miracle. The eventual death of the system itself, coupled by increasing administrative measures with no consideration for economic theory, proved to have only significant negative results. From 1952-1962, the annual Gross National Product averaged an impressive 8,2 percent ; by 1980-1988, the GNP average had slowed to a trickle- 0,6 percent $^{62}$.

One central "cause" for self-management's failure, nonetheless, can be explained simply in human terms. While Yugoslavs did manage themselves within factories to a considerable degree, they also acted in what should be considered the most human way in an environment that allowed them to act freely. With little regard for production, 
workers, obsessively perhaps, pursued what in Serbo-Croatian was called trka za dinarom (running after dinars). Workers raised wages.

This inherent "self"-incentive, uncoupled from an equal rise in production rates and along with a rash of unwise governmental economic investments, along with an increasingly liberal lending policy without regulatory control (quite similar to the practices that led to the Southeast Asian economic crisis of 1997), produced inevitable results. Unlike the International Monetary Fund intervention in controlling the economic crisis of 1997 in South Korea, however, Tito refused "market intervention", advocated laissez-faire economics, and relied on the law of supply and demand ${ }^{63}$. For an avowed Communist and for what was doctrinally a Communist state, this intervention refusal seems extraordinary.

In the words of Adam Smith, the "skill, dexterity, and judgment [applied to] the greatest improvement in the productive powers of labour [sic]» lead to the most effective results ${ }^{64}$. By contrast and partially as a counter-response to the "exploitation" of the laborer, Marx saw future capitalist, free market societies as practicing a modern theory of colonization : «the only thing that interests the new world [is] the political economy of the old world (...) the capitalist mode of production and accumulation, and therefore capitalist private property, have for their fundamental condition the annihilation of self-earned private property; in other words, the expropriation of the labourer $»^{65}$ [sic]. Today, in the post-Cold War and post-Yugoslav era, both Smith's and Marx's words contain essential truths and contradictory tensions. The necessary balance is to harmonize the needs of the worker with marketplace profit.

Self-management in former Yugoslavia was imposed from the top down (by the government), rather than pushed forward from the bottom up (by the workers for whom self-management was first established "to protect"). Self-management, in its way, proved an acceptable substitute for self-government until its inherent weaknesses betrayed it.

Thus, some essential "ecological" truths about societal structure may be gleaned from the experience of failure. These truths include variations on the theme that the basic rights of a civil society must prevail and the individual citizen must have the right to exercise a voice that cannot exist in a one-party state. The Staatsrecht-a state in which the rule of law allows the guarantee of civil rights, including self-governing rights, and the independence of social activities-should prove the essential guarantor of societal stability ${ }^{66}$. In essence then, the idealized Yugoslav "de-etatization"-the "withering away of the state" - which began in 1955 and was foreseen to finally allow self-managed organizations to take control, was impossible. Some form of higher level control, at a federal level, was required ${ }^{67}$.

The economic failure of Yugoslavia is linked to human failures in motivation and control. Yet what happened in Yugoslavia (and may happen again) is a possibility in the new Europe-one that includes West, East, the Caucasus, the Crimean Basin, Central Asia, and the Balkans. Aside from the widespread environmental damage (both human and natural) done to Yugoslavia, the process of economic growth came to reject Marx's reform-minded conception of the reconciliation of humanity with nature; in essence, Yugoslavia rejected both the technological and human factors that were required for its continued existence ${ }^{68}$. management at its core intended itself to be, works best-and perhaps works only-at 
the level of small enterprise. The Yugoslav state, nonetheless, was the ultimate decision maker; this was also a one-party, non-democratic system that sanctioned, in its final days, every important aspect of executive decision making ${ }^{69}$. Thus, the issue of transparency of a company, popular in contemporary terms, is also a relevant one. Selfmanagement failed because the Yugoslav government would not allow true worker democracy ; the Yugoslav self-managed worker likely had far less power than a worker in private enterprise who belonged to an effective trade union ${ }^{70}$.

As Gapisnki, Škegro, Zuehlke point out, even an American political system would prove itself incapable of change when all inevitable decisions meant only substantial income losses $^{71}$. The Yugoslav example by the late 1980's showed that unless reform had an immediate short-term effect and did not overcome worsening of the distribution of gains losses, the reform itself was bound to fail. The status quo, no matter how terminally ill its central core might be, became the standard to protect.

Statistical evidence shows that Yugoslav workers acted most often out of motivation only to increase personal income; such "motivation" may equally have come to influence official state ideology ${ }^{72}$. Thus, the "system" of self-management had little to do with the act of managing daily life. By contrast, Yugoslavia and Yugoslavs became preoccupied (some might say obsessed) with the standard of living ${ }^{73}$.

The disintegration of Yugoslavia, and the creation of six newly independent states (Serbia, Macedonia, Montenegro, Croatia, Slovenia, Bosnia-Herzegovina) was the partial result of different approaches and transition processes in the move from publicly to privately owned market-economy structures. Along with the disintegration of a federal structure came the disintegration of federal legal structures that might have regulated such transition between Yugoslav republics ${ }^{74}$.

Even the significant economic reforms of the late 1980's and early 1990, uncoupled from other ecological factors that would insure societal stability, proved fruitless. Prime MinisterAnte Marković's economic austerity program of the late 1980's saw the inflation rate drop from a high of 2500 percent in 1989 to 8,4 percent in February 1990. Further, Markovićs Communist Reform Party, a true coalition of Yugoslav identitiesfavoring revisionist Islamic, Serbian, Croatian, and socialist elements-showed the potential of a continued Yugoslav identity along with a major program of economic reform ${ }^{75}$.

54 Yet, despite the influence of often overwhelming government regulation, banking system reform and the expansion of competition through the increase of private enterprise and increased foreign investment, Markovićs economic reforms provided a temporary, but not long-term, solution. By 1993, what remained of Yugoslavia under the mantle of Slobodan Milošević was a ruin : the Yugoslav Statistics Bureau revealed that inflation that year grew at a rate of 0,7 percent an hour, 20190 percent monthly, and translated into an annual inflation rate of 286 billion percent ${ }^{76}$.

The true ecological meaning of self-management's failure-and the subsequent failure of the state-lay in how an innovative system could not be sustained by the structure that nominally provided support for it. (Further damaging were well intentioned international efforts to economically blockade Serbia and Montenegro after Yugoslavia's demise.) Such ecological devastation to the environment and to the peoples of former Yugoslavia resulted in hundreds of thousands of deaths, millions of 
refugees, economic repercussions that continue today, and a perplexing security problem for future European stability.

The extraordinary change in "culture" during the decades of self-management appears now to have been insufficient to transform the Yugoslav themselves. By contrast, the galvanizing post-World War II force of Communist ideology and partisan resistance proved sufficient to unite a population toward the goal of national liberation while equally providing sufficient force to "mobilize" this sentiment in postwar reconstruction ${ }^{77}$. Such fervor could not, and did not, last forever.

\section{The Significance of Failure}

57 In his 1971 memoir, former Yugoslav economic minister (in the early 1950's) Svetozar Vukmanović-Tempo suggested that the best strategic "weapon" Yugoslavia could use against the United States would be to send two Yugoslav planners to help ruin the American economy ${ }^{78}$. The Yugoslav example is not an isolated one. While Yugoslavia represented in its time a significantly "experimental" socialist society-one that allowed freedom of travel for its citizens and toyed with various free market ideas-the meaning of its disintegration should not be considered in isolation. Indeed, the neighboring nation of Bulgaria, which during the 1990's hovered near economic collapse after casting off its Cold War socialist legacy, demonstrated how fundamental tensions between democratic practices, economic reforms, and competing governmental forces hold the potential for the breakdown of political and civil order ${ }^{79}$. Bulgaria, nonetheless, managed to survive despite these tensions. The economic failure of the Yugoslav state, of which self-management was a major contributing factor in Yugoslavia's post-World War II history, may well replicate itself in future instabilities both in Central Europe and in various nations of the former Soviet Union.

What remains perhaps most significant about the Yugoslav "Experiment" lies in how far ahead of its time it was. The post-World War II "new" Yugoslavia was a decentralized nation of six federated republics and two self-governing regions (Vojvodina and Kosovo). Democratic participation, albeit under a strict one-party rule, was a uniquely Yugoslav innovation; a collision course with the Soviet Union in 1948 seems now, in retrospect, inevitable. At the same time, the structure of the internal security mechanism within Yugoslavia was the most powerful in Eastern Europe ${ }^{80}$. This seeming contradiction is significant in its implication for the future Europe: in the inevitable decentralization of power in Yugoslavia, the central oligarchy became eventually replaced by separate, often contradictory and frequently competitive oligarchies ${ }^{81}$. The fracturing of the state became not only a struggle for control of scarce resources but an ideological battle for nationalist identity.

Tito's own political entrenchment follows the pattern of Yugoslavia's progressive-and by extension, social-decline. Expelled from the Cominform in 1948, Tito approved the self-management initiative that began its golden "miracle" era in 1953. That same year, Tito was re-elected president after his first five-year term and repeatedly re-elected. In 1963, the year that marked self-management's "miracle" end and its permanent decline, Tito was elected president for an unlimited term. In 1971, Tito was established as chairman of the newly created collective presidency and Yugoslavia entered a descending spiral fueled by contributory, ecological factors that led to its inevitable disintegration. The economy itself, a major contributory factor of significance in the 
death of Yugoslavia, weakened in the 1970's under high inflation, increasing foreign debt, and inefficient industry.

In a remarkably prescient article that appeared in The Atlantic Monthly in December 1962, journalist Fred Warner Neal correctly questioned the viability of selfmanagement's continued success under a Titoist system ${ }^{82}$. Although Neal articulated the miraculous transformation of an agricultural society to a competitive industrial economy in the space of two decades, he also noted the numerous potential weaknesses of its system. While production in 1961 showed the sharpest increases worldwide, the inherent contradictory pressures of free enterprise and collective ownership, in essence a unique blend of Keynesianism and Marxism, was bound to lead to a bad end. Yugoslavia, as a breakaway Communist state that clearly differed from the Soviet paradigm, also received significant foreign aid: various claims show that the United States gave Yugoslavia $\$ 1,5$ billion in economic assistance from 1950 to 1959 as well as $\$ 724$ million in military assistance ${ }^{83}$.

61 The economic reforms that foreign creditors and "Western" governments essentially demanded of Yugoslavia in its final days required an authoritarian regime to voluntarily reduce its own powers even as contrarian human and technological forces demanded that the Yugoslav government retain what little authority it still possessed in order to provide a stable transition period. The failure of the Yugoslav state to provide such necessary order during a time of variously attempted economic and democratic reforms was a factor that allowed ultra- "nationalist" forces to take hold, forces that opposed the continuation of a "Yugoslav" state.

The Yugoslav example thus provides a pertinent example of how the pressures of societal expectations coupled with an eroding social fabric in a condition of weak state authority and intrastate tensions can often lead to conflict. From a social and strategic management perspective, the lessons of post-Yugoslav Serbia as well as BosniaHerzegovina foretell a potentially bleak future for European stability. The innovation of Yugoslav self-management, once considered a benchmark in creative economic reform within a socialist society, proved to be a major contributing factor in the death of Yugoslavia.

\section{Implications for State and Regional Stability}

63 A number of inferences for future European stability, if not lessons, can be drawn from the Yugoslav experience. First, as Spegele has noted in regard to international economics, the notion that the core motivation for robust globalism is human emancipation (that is, in a political and societal context, the embedding of constitutional liberalism within a social framework), takes its logic not from the writings of Adam Smith, but from Marxist tradition ${ }^{84}$.

Secondly, in what is perhaps the most extraordinary irony of the post-Cold War era: the most pertinent and cautionary critic of globalism and free market incentives that are not tied to responsible social initiatives is none other than the scourge of capitalism, Karl Marx. A review of Marx's writings, particularly Das Kapital, reveals sufficient evidence, in an age of globalism, that side effects of globalization-corporate tax shelters, child labor, closed down factories, dwindling social support programs-can lead more toward global disintegration than integration if taken to an extreme ${ }^{85}$. While Marx seems clearly to have erred in his trumpeting of the coming triumph of 
Communism, he may well remain the most accurate critic of (current and future) capitalism in its purest form.

Thirdly, as a number of economic observers have begun to realize, economic flexibility and societal cohesion are inherently linked factors in periods of political transformation. Continued emphasis on globalization, which in a European context is best represented by the expansion of the European Union, requires considerable economic, social, and cultural adaptation-even within societies and cultures linked by common history and heritage ${ }^{86}$.

Finally, the most critical and difficult implication for future European stability lies in a continued commitment to support those structures "outside" the framework of a strategic vision that seeks only economic gain. The most pertinent example, of course, is that of Bosnia-Herzegovina. Although the International Monetary Fund and the World Bank have recently placed increased importance on macroeconomic structural programs that are coupled to demands that governments both root out corruption and respond to stricter internal reforms ${ }^{87}$, it remains far too early to predict the success of Bosnia as a future state.

The most likely outcome is that Bosnia, if it survives, will become a weak, economically fragile, and relatively unstable nation for some time to come. Equally, Bosnia will require significant support in the form of military (the 36 member NATO-led Stabilization Force) and economic (World Bank) assistance. As for Serbia, continued ostracism by the international community-particularly by the United States-will both prolong and exacerbate integration within the European security architecture. Economic assistance for both Bosnia and Serbia, as Susan Woodward has noted, should not allow the continued opportunity for local crime networks to capitalize on foreign investment and route construction activities, transport operations, and other foreign assistance to the benefit of dominant political parties, state corruption, and provide future opportunities for the proliferation of criminal activity ${ }^{88}$.

The dangers for the future post-Yugoslav states, thus, are similar to the dangers all post-Cold War Europe faces. From the perspective of the classical liberalist thinker, Ralf Dahrendorf, these dangers rise squarely out of conditions that exist when " economic values begin to dominate politics (... ) [and] liberty is at risk. The new economism of capitalism is no less illiberal that the old one of Marxism ${ }^{89}$. The challenge for European stability, as Dahlendorf examines it, is to reconcile the often contradictory tensions of prosperity, solidarity, and liberty. Indeed, as the disastrous Yugoslav example illustrates, economic growth and economic disintegration are conditions that rarely, if ever, occur in isolation.

\section{NOTES}

1. Clinton (President William Jefferson), A National Security Strategy of Engagement and Enlargement, Washington, D.C. : U.S. Government Printing Office, 1996. 
2. Marshal Tito, interviewed by Henry Fairlie, [The Queen, (5497), 18 September 1962], in Sirc (Ljubo), The Yugoslav Economy under Self-Management, New York : St. Martin's Press, 1979, p. v.

3. Clinton (President William Jefferson), A National Security Strategy of Engagement and Enlargement, Washington, D.C.: U.S. Government Printing Office, 1994; Clinton (President William Jefferson), op. cit., 1996, p. 2; Clinton (President William Jefferson), A National Security Strategy for a New Century, Washington, D.C. : U.S. Government Printing Office, 1997.

4. Zakaria (Fareed), "The Rise of Illiberal Democracy », Foreign Affairs, November-December 1997, pp. 22, 38 ; Carothers (Thomas), « Promoting Democracy in a Postmodern World», quoted in «Which Democracy Should We Export?» Harper's,September 1996, p. 17; Carothers (Thomas), « Democracy without Illusions », Foreign Affairs, January-February 1997, pp. 85-87.

5. Zakaria (Fareed), loc. cit., p. 22.

6. Holbrooke (Richard), «America, a European Power », Foreign Affairs, March-April 1995, pp. 39-43 ; Christopher (Warren), "The CSCE Vision : European Security Rooted in Shared Values ", Statement to the Plenary Session of the Conference on Security and Cooperation in Europe, Rome, 30 November 1993 ; Christopher (Warren), « Toward a More Integrated World ", Statement at the Organization for Economic Cooperation and Development (OECD) Ministerial Meeting, Paris 8 June 1994.

7. Woodward (Susan), Balkan Tragedy: Chaos and Dissolution after the Cold War, Washington, D.C. : The Brookings Institution, 1995, p. 17.

8. National Public Radio's All Things Considered, 20 December 1997. Serbian voters, through an intentional boycott, failed to elect a Serbian president from the two candidates, Vojislav Šešeljthe "fascist"-and the protégé of Milošević, Zoran Lilić-the "communist". Until 24 December 1997, neither candidate was able to capture 50 percent of the popular (registered) vote. On that date, the results of a fourth presidential election were announced, in which another protégé of Milošević, Milan Milutinović, was declared the newly elected president of the Serbian republic.

9. Woodward (Susan), op. cit., p. 17.

10. The name "Tito" comes from Josip Broz's effective organizational skills in leading the communist resistance movement from 1937 on. After Gorkić, the Secretary General of the Yugoslav Communist Party, was "liquidated", Tito took his place immediately, earning a reputation for telling subordinates where to go and what to do : « You (ti) will do this (to) ... You (ti) will do that (to) -Ti, to; ti, to » (Maclean 1964, p. 316).

11. Bertsch (Gary K.), Ganschow (Thomas W.), Comparative Communism : The Soviet, Chinese, and Yugoslav Models, San Francisco : W. H. Freeman and Company, 1976, pp. 131-132.

12. Djilas (Milovan), Conversations with Stalin, New York: Harcourt, Brace \& World, 1962, pp. 10-11; Banac (Ivo), With Stalin against Tito: Cominformist Splits in Yugoslav Communism, Ithaca : Cornell University Press, 1989, pp. 255-267.

13. Neal (Fred Warner), "Yugoslavia at the Crossroads ", Atlantic Unbound (from the original December 1962 Atlantic Monthly article), 3 December 1997.

14. Chesbrough (Henry W.), Teece (David J.), «When is Virtual Virtuous? Organizing for Innovation », Harvard Business Review, January-February 1996, pp. 65-73.

15. Schrenk (Martin), Ardalan (Cyrus), El Tatawy (Nawal E.), Yugoslavia: Self-Management Socialism and the Challenges of Development (Report of a Mission Sent to Yugoslavia by the World Bank), Baltimore : The Johns Hopkins University Press, 1979, pp. 375-376.

16. Zukin (Sharon), Beyond Marx and Tito: Theory and Practice in Yugoslav Socialism, Cambridge : Cambridge University Press, 1975, p. 61.

17. Neal (Fred Warner), loc. cit.

18. Sirc (Ljubo), op. cit., p. 2 ; Zukin (Sharon), op. cit., pp. 57-58.

19. Zukin (Sharon), op. cit., p. 57.

20. Gapinski (James H.), Škegro (Borislav), Zuehlke (Thomas W.), Modeling the Economic Performance of Yugoslavia, New York : Praeger, 1988, p. 32. 
21. Zukin (Sharon), op. cit., pp. 48-49.

22. Lydall (Harold), Yugoslavia in Crisis, Oxford : Clarendon Press, 1989, pp. 102-103, 104-105.

23. Ramet (Sabrina Petra), Social Currents in Eastern Europe: The Sources and Meaning of the Great Transformation, (2nd edition), Durham : Duke University Press, 1995, p. 333.

24. Neal (Fred Warner), loc. cit.

25. Kovać (Oskar), «Foreign Economic Relations », in Adamovich (Ljubiša S.), Ramet (Sabrina Petra), eds., Beyond Yugoslavia: Politics, Economics, and Culture in a Shattered Community, Boulder : Westview Press, 1995, p. 282.

26. Neal (Fred Warner), loc. cit.

27. Ibid.

28. Woodward (Susan), Socialist Unemployment: The Political Economy of Yugoslavia, 1945-1990, Princeton : Princeton University Press, 1995, pp. 168-169.

29. Neal (Fred Warner), loc. cit.

30. Lydall (Harold), op. cit., p. 104.

31. Idem, p. 105.

32. U.S. Department of State [USDS], Country Reports on Human Rights Practices [CRHRP], Washington, D.C. : U. S. Government Printing Office [USGPO], 1987, p. 1085.

33. USDS, CRHRP, Washington, D.C. : USGPO, 1988, p. 1265.

34. USDS, CRHRP, Washington, D.C. : USGPO, 1990, pp. 1275-1277, 1262.

35. USDS, CRHRP, Washington, D.C. : USGPO, 1991, p. 1358.

36. USDS, op. cit., 1988, pp. 1263-1264.

37. Lydall (Harold), op. cit., pp. 109-119.

38. Ibid., p. 120.

39. Gapinski (James H.), Škegro (Borislav), Zuehlke (Thomas W.), op. cit., p. 32.

40. Kornai (János), Economics of Shortage, Amsterdam : North-Holland Publishing Company, 1980 (Quoted in Gapinski (James H.), Škegro (Borislav), Zuehlke (Thomas W.), op. cit.).

41. Lydall (Harold), op. cit., pp. 4-5.

42. Macesich (George), The International Monetary Economy and the Third World, New York: Praeger Special Studies, 1981, p. 240.

43. Lydall (Harold), op. cit., p. 7.

44. Woodward (Susan), Socialist Unemployment (op. cit.), p. 186.

45. Idem, p. 191.

46. Idem, p. 335.

47. USDS, op. cit., 1987, p. 1084.

48. USDS, CRHRP, Washington : USGPO, 1983, p. 1171 ; USDS, CRHRP, Washington : USGPO, 1989, p .1267 .

49. USDS, op. cit., 1990, p. 1342 ; USDS, op. cit., 1991, p. 1309.

50. In 1971, Tito created a rotating 22 members collective presidency that served a five-year term. The federal presidency was composed of the presidents of the six republics and two autonomous provincial assemblies, as well as 14 members selected from republican and provincial assemblies. Tito also established rotation in top federal positions, nominally so that representatives of republics and provinces would serve on a collective body, the Federal Executive Council, to implement decisions and carry out duties normally accomplished in other countries by a single president.

51. Lydall (Harold), op. cit., pp. 236-237.

52. Idem, p. 237.

53. Zukin (Sharon), op. cit., pp. 248-249.

54. Mencinger (Jo`e), « From a Communist to a Capitalist Economy?» in Dekleva (Jo`e), Simmic (James), eds., Yugoslavia in Turmoil : After Self-Management, London : Pinter Publishers, 1991, p. 73. 
55. Dekleva (Jo`e), Simmie (James), "General Lessons from the Yugoslav Experience ", in Dekleva (Jo`e), Simmic (James), eds., op. cit., p. 145.

56. Idem, pp. vii, 152-153.

57. Lydall (Harold), op. cit., pp. vi-vii.

58. Golubović (Zagorka), "Characteristics, Limits and Perspectives of Self-Government: A Critical Reassessment », in Dekleva (Jo`e), Simmic (James), eds., op. cit., p. 32.

59. Adapted from idem, pp. 37-38.

60. Adamović (Svetlana), Pavlović (Vukašin), « Environmental Issues and Policies, with Special Attention to Montenegro », in Adamovich (Ljubiša S.), Ramet(Sabrina Petra), eds., op. cit., pp. 309-310.

61. Woodward (Susan), Socialist Unemployment (op. cit.), p. 256.

62. Mencinger (Jo'e), loc. cit., p. 78.

63. Neal (Fred Warner), loc. cit.

64. Smith (Adam), An Inquiry into the Nature and Causes of the Wealth of Nations. Great Books of the Western World, Chicago : Encyclopædia Britannica, Inc., 1952, p. 3.

65. Marx (Karl), Capital, Chicago : Encyclopædia Britannica, Inc., 1952, p. 379.

66. Golubović (Zagorka), loc. cit., p. 43.

67. Šmidovnik (Janez), «Disfunctions [sic] of the System of Self-Management in the Economy, in Local Territorial Communities and in Public Administration », in Dekleva (Jo`e), Simmic (James), eds., op. cit., pp. 28-29.

68. Adamović (Svetlana), Pavlović (Vukašin), loc. cit., p. 308.

69. Lydall (Harold), op. cit., p. 108.

70. Idem, p. 109.

71. Gapinski (James H.), Škegro (Borislav), Zuehlke (Thomas W.), op. cit., p. 228.

72. Zukin (Sharon), op. cit., p. 72.

73. Idem, p. 98.

74. Adamovich (Ljubiša S.), «Economic Transformation in Former Yugoslavia, with Special Regard to Privatization », in Adamovich (Ljubiša S.), Ramet(Sabrina Petra), eds., op. cit., p. 275.

75. U.S. Department of State, op. cit., 1990, p. 1342.

76. Maass (Peter), Love Thy Neighbor: A Story of War, New York : Vintage Books, 1996, p. 228.

77. Zukin (Sharon), op. cit., p. 235.

78. Sirc (Ljubo), op. cit., p. 9.

79. Woodward (Susan), Balkan Tragedy (op. cit.), p. 15.

Bulgaria's extraordinary, and often halting, recovery can, nonetheless, be taken as a sign of guarded optimism for future European stability. Although Bulgaria suffered significant negative growth in the mid-1990's, strict economic measures coupled with sufficient societal guarantees for citizens produced some positive result. Perhaps the most positive result occurred on 13 December 1997, when Bulgaria (along with Romania, Latvia, Slovakia, and Lithuania) was granted "second wave" consideration for accession talks as an eventual full European Union member.

80. Glenny (Misha), The Rebirth of History, London : Penguin, 1990, p. 120.

81. Davidson (Basil), The Black Man's Burden: Africa and the Curse of the Nation-State, New York: Times Books, 1992, pp. 281-282.

82. Neal (Fred Warner), loc. cit.

83. "Major Expansion of Arms Sales to Yugoslavia Planned by US ", Aerospace Daily, 28 September 1978; Weintraub (Bernard), "US to Sell Arms to Yugoslavia and Widen Military Cooperation », Current News , 29 September 1978 ; Neal (Fred Warner), loc. cit.

84. Spegele (Roger D.), «Is Robust Globalism a Mistake? ", The Review of International Studies, April 1997, p. 237.

85. Cassidy (John), « The Return of Karl Marx », The New Yorker, 20-27 October 1997. 
86. Miller (Riel), "Economic Flexibility and Societal Cohesion", The OECD Observer, AugustSeptember 1997, p. 24.

87. New York Times, 11 August 1997, p. A1.

88. Woodward (Susan L.), « Bosnia after Dayton : Year Two », Current History, March 1997, p. 103.

89. Cohen (Mitchell), "Review of After 1989: Morals, Revolutions, and Civil Society by Ralf Dahrendorf », New York Times Book Review, 23 November 1997, p. 17.

\section{AUTEUR}

\section{P. H. LIOTTA}

P. H. Liotta is the Jerome E. Levy Chair of Economic Geography and National Security at the U.S. Naval War College. He previously served as a Fulbright scholar to Yugoslavia during its breakup as a nation-state and as a diplomatic attaché to the Hellenic Republic. He has traveled extensively throughout the former Soviet Union, Europe, and the Balkan peninsula. The author of ten books and over 250 articles in fields as diverse as poetry, criticism, education, international security, intervention ethics, and foreign policy analysis, his work has been translated into Arabic, Bosnian, Bulgarian, French, Greek, Italian, Japanese, Macedonian, Russian, Serbo-Croatian, and Spanish. He has received a Pulitzer Prize nomination and National Endowment for the Arts literature fellowship, as well as the first International Quarterly Crossing Boundaries Award and the Robert H. Winner Award from the Poetry Society of America. A member of the advisory board for the Research Institute for European and American Studies, he has also been a visiting lecturer at the University of Athens and Complutense University in Madrid and visiting writer at SUNY Binghamton and the California Institute for the Arts. 